SHANKAR SANKARAN

\title{
5. ACHIEVING SYNERGY THROUGH COMBINING ACTION LEARNING AND ACTION RESEARCH
}

\author{
INTRODUCTION
}

Today the complementarity between action learning and action research has achieved form in the concept of ALAR: Action Learning and Action Research. The synergy between these two has been built since the formation of ALARPM (Action Learning, Action Research and Process Management) in Brisbane in 1991, through the insight and action of a number of scholars influenced by the work of Ortrun Zuber-Skerritt. Ortrun has championed this unison of 'Action' through her scholarship and her personal efforts to draw together people, ideas and purposes, as her instrumental role in formation of the Action Learning and Action Research Association (ALARA) attests. In this chapter I therefore pay tribute to Ortrun's contributions to knowledge and professional development not just through action learning and action research but also through her quest to achieve the synergy between learning and research through her writings and work. As evidence of Ortrun's influence, I offer my personal experience of effectively combining action learning and action research in a workplace project to meet the real challenges I faced as senior manager in a Japanese company in Singapore simultaneously needing to satisfy the requirements of my doctoral thesis at an Australian university. This experience reveals not just the influence of Ortrun's scholarship on my learning and research but also the trans-cultural flexibility of the action learning-action research combination at a time when globalisation makes this quality not just useful but necessary for solving real problems (Sankaran \& Kumar, 2010).

The chapter is organised as follows. First, I briefly review action learning and action research and their usefulness in producing actionable and rigorous outcomes. I then discuss similarities and differences between action learning and action research, and then explain how they can be combined in university doctoral programs to help produce management and research outcomes. I conclude with discussion of why I think doctoral researchers who are interested in improving their workplace as an outcome of their research can find it useful to consider combining action learning and action research.

J. Kearney \& M. Todhunter (Eds.), Lifelong Action Learning and Research, 47-63.

(C) 2015 Sense Publishers. All rights reserved. 
S. SANKARAN

BRIEF REVIEW OF ACTION LEARNING AND ACTION RESEARCH

In this section I briefly review action learning and action research and their similarities and differences before I discuss how they can be combined. As these two topics are very broad I confine the discussion to some key thoughts about them. For each, I begin with the ideas of originator of the concept and then provide current, generally accepted definitions from what I consider as reliable sources. I then present ideas from other authors, including Ortrun, whose works informed my thinking and research. These helped in my journey to make sense of these two approaches as I tried to meld them to maximise their utility, as I became an action researchercum-learner while employed as a senior manager. I incorporate Ortrun's views on both concepts in these discussions, revealing the amplifier effect of her influence in the field - upon myself as researcher and manager, upon research students I have supervised and guided at doctoral and masters level, and upon many others through my research and publications.

\section{Action Learning}

Reg Revans is considered the father of action learning, a process he discovered by observing how reputed scientists working in the Cambridge University Laboratory in the 1940s learnt from each other. In one of his early writings about action learning (Revans, 1983, p. 43), he came close to explaining what it is by stating: 'Action learning, by encouraging men of practice to clarify to each other (not to P-men, the experts) what they believe their problems to be, including their own selves as part of the nightmare, and what they think ought to be done about them, provides an effective workshop for examining, sharpening and testing their managerial weapons - above all, their judgement of the unseen and of the unknown'. He adds (Revans, 1983 , p. 43) that these practitioners should use the following steps to carry out action learning to solve their problems:

1. By contact with responsibility and reality, facing honesty of expression from start to finish;

2. The constant interpretation by equal comrades of what one is seen to be doing and saying; and

3. Reciprocally offering one's own advice, criticism and support back to those very same comrades.

Revans noted that these three characteristics of action learning differentiated it from all other forms of management education.

The International Foundation of Action Learning in the UK (http://ifal.org.uk/ action-learning/), which was established on the principles Revans proclaimed, further elaborates his description of action learning: 
Action Learning involves working on real problems, focussing on learning and actually implementing solutions. It is a form of learning by doing. Pioneered by Professor Reg Revans and developed worldwide since the late 1940s, it provides a well-tried method of accelerating learning, which enables people to handle complex issues more effectively.

Action Learning is based on a radical concept: $\mathrm{L}=\mathrm{P}+\mathrm{Q}$. Learning requires Programmed knowledge (i.e., knowledge in current use) plus Questioning insight. It also uses a small group to provide challenge and support: individuals learn best with and from one another as they each tackle their own problem and go on to actually implement their own solution.

The process integrates: research (into what is obscure); learning (about what is unknown); and action (to resolve a problem) into a single activity and develops an attitude of questioning and reflection to help individuals and organisations change themselves in a rapidly changing world.

Revans emphasised that ' $Q$ ' is the most important part of the learning equation, stating that 'the search for $\mathrm{Q}$ is the mission of action learning, and it is pursued in a learning community' (Revans, 1983, p. 41).

Mike Pedler, the Revans Professorial Fellow at Salford University who has also republished Revans's books, explains that Revans may have resisted defining action learning clearly (Pedler, 1997a, p. xxx) because he felt it was a 'philosophy', thus preventing it from being adopted as a management technique. This disposition is reflected in what Revans writes about the 'philosophy of action learning', where he states, 'Action Learning is the Aristotelian manifestation of all managers' jobs: they learn as they manage; and they manage because they have learned - and go on learning' (Revans, 1998, p. 73).

Pedler, however, ventures to offer his own definition to help newcomers learn the essence of action learning.

Action learning couples the development of people in work organizations with action on their difficult problems. It is based on the premise that there is no learning without action and no sober and deliberate action without learning. This contrasts with the principles underlying most of our formal education. Action learning makes the task the vehicle for learning and has three main components - people, who accept the responsibility for action on a particular task or issue; problems or the tasks which are acted on; and the set of six or so colleagues who meet regularly to support and challenge each other to take action and to learn. Action Learning implies both organizational development and self-development - action on a problem changes both the problems and the actor. (Pedler, 1997a, p. xxx)

As you can observe, this definition helps to differentiate action learning more clearly from other forms of management development by elaborating on its main components. 


\section{S. SANKARAN}

In my early days as an action learner, Mike Pedler's book Action Learning in Practice (1997b) came in very handy to set up an action learning set in my organisation. Pedler was also involved in setting up the journal Action Learning: Research and Practice, which publishes refereed papers and accounts of practice.

In spite of Pedler's caution, over the years action learning has become a tool for management consultants in management development work. It has also found wide application in large organisations like General Electric, Prudential, Astra Zeneca and Sandvik, which indicates that it works in practice.

Attempts were also made to introduce action learning in management education programs, using it as a way of teaching instead of lecturing. A recent study by Pedler, Burgoyne and Brook (2014, p. 65), however, concludes that 'business school education remains dominated by the traditional lecturing and case studies and that action learning is not widely used nor are business school staff generally skilled in it'. However, interestingly their research found that action learning has been developed from being a method to being an ethos (Pedler et al., 2014, p. 58), 'a general approach to learning from experience through engaging with actual work challenges rather than the ones described (case studies) or simulated (businessgaming, role-playing) in classroom situations'. They also found new variants of action learning such as Critical AL, Auto AL, Action mentoring, online and remote action learning, self-managed $\mathrm{AL}$ and Business-Driven $\mathrm{AL}$.

Pedler and Burgoyne (2008, p. 321) sampled practitioners in the United Kingdom to identify the essential features of action learning that are commonly used, and produced the following list:

1. Sets have about six people.

2. Action is on real tasks or problems at work.

3. Tasks/problems are individual rather than collective.

4. Questioning is the main way to help participants proceed with their tasks and problems.

5. Facilitators are used in the AL process.

6. Tasks/problems are chosen independently by individuals.

Ortrun provides a briefer definition of action learning as 'learning from concrete experience and critical reflection on the experience - through group discussion, trial and error, discovery and learning from each other' (Zuber-Skerritt, 2002, p. 114). Her definition sets some preconditions that are required to make action learning successful. Through her experience setting up the Queensland University Action Learning Program (QUAL), she stresses that certain values are important for action learning programs to succeed. These include:

1. Collaboration, trust and openness;

2. Team spirit and mutual respect for individual differences, talents and needs; and

3. Tolerance of mistakes, from which we learn (Zuber-Skerritt, 2002, p. 114). 
Can action learning be taught? There are several guides and case studies on how to set up an action learning program (Pedler, 2008), but one often hears the statement that you learn action learning only by doing it and experiencing it. This is what happened when as part of my doctoral research I first started to set up an action learning program in the organisation where I worked as senior manager in Singapore. While the task seemed simple, it took us some time to learn about and practise action learning properly. We learnt about it through organising an action learning workshop and learning by ourselves, with each other, how to do it. I then sought some help from a consultant.

In my search for materials about action learning I came across a very practical book by Scott Inglis (1994), Making the Most of Action Learning, which I liked for its simple and practical explanation. We were starting an action learning set in Singapore and did not have the funds to invite Inglis from the UK to conduct a startup workshop. So we wrote to him and he was kind enough to send all his slides to help us conduct a start-up workshop that we found very useful.

Often action learning guides also advocate the use of a facilitator (or set adviser) to keep the set honest in following the principles of action learning. However, we decided to take on the role of the set adviser ourselves, which often happens when action learning sets mature and become self-sustaining. We found very useful the fish-bowl exercise recommended by McGill and Beatty (2001) to practise 'insightful questioning'. As managers we had been ready to rush forward towards solutions in our set meetings, instead of going through the process of 'peeling the onion' to understand the problem we were facing using an insightful questioning process. Once we mastered this, it was smooth sailing with the set.

When we were trying to make sense of action learning, a workshop conducted by Ron Passfield from Brisbane in Australia helped me to better appreciate and adopt in our action learning set some essential features and values based on Passfield's own doctoral research (Passfield, 1996, p. 19):

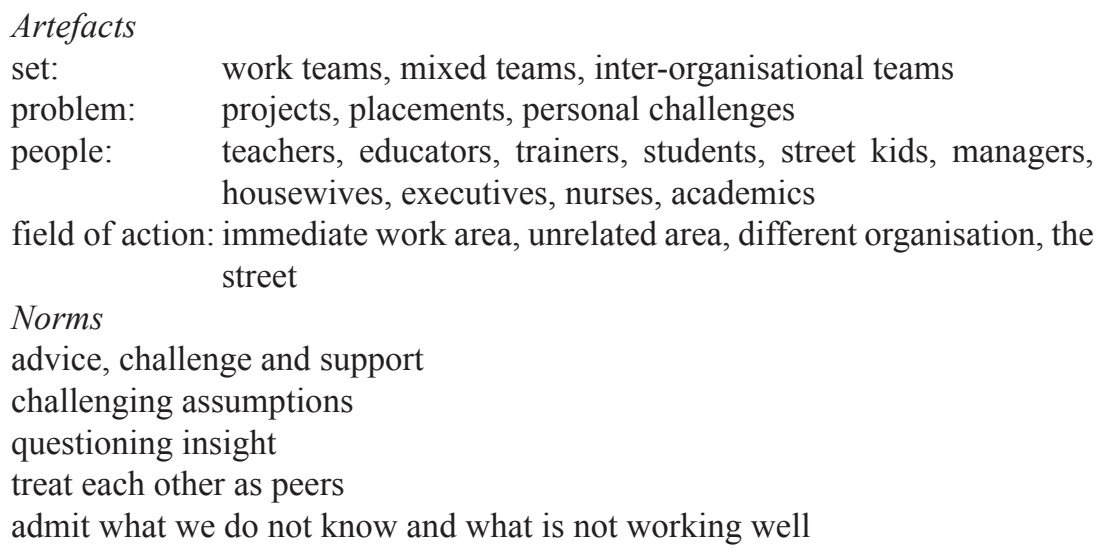




\section{S. SANKARAN}

take a system perspective

accept responsibility for own actions and learning

Values

inclusiveness and respect for diversity

honesty and integrity

collaboration

relationships are important

Assumptions

$\mathrm{L}=\mathrm{P}+\mathrm{Q}$ (learning equals programmed knowledge plus questioning insight).

Current knowledge and skill are born of lived experiences in a previous time and space and, in that sense, are environmentally relative.

Past experience can generate misconceptions, not only because our perceptual capacity is limited, but also because the past is different from the present and the future.

Learning can be defined as 'our ability to adapt and change with such readiness that we are seen to change'. (Revans, 1981, p. 136)

People learn with and from each other when they acknowledge their common ignorance and vulnerability.

Learning is a social process involving collaborative reflection on action.

Passfield's explanation of the features summarised above informs us on several aspects and can be used as a quick guide to set up action learning. Another resource that I found helpful for setting up action learning to develop younger managers in the organisation where I worked was Alan Mumford's (1993) book, How Managers Can Develop Managers. Our learning set found it helpful to use the 'task cycle' and 'learning cycle' used in the book, which is derived from Kolb's learning cycle. The two cycles helped us to deliberately set learning goals before we undertook a task related to the overall problem we were working with on a large-scale change initiative. See Figure 5.1.
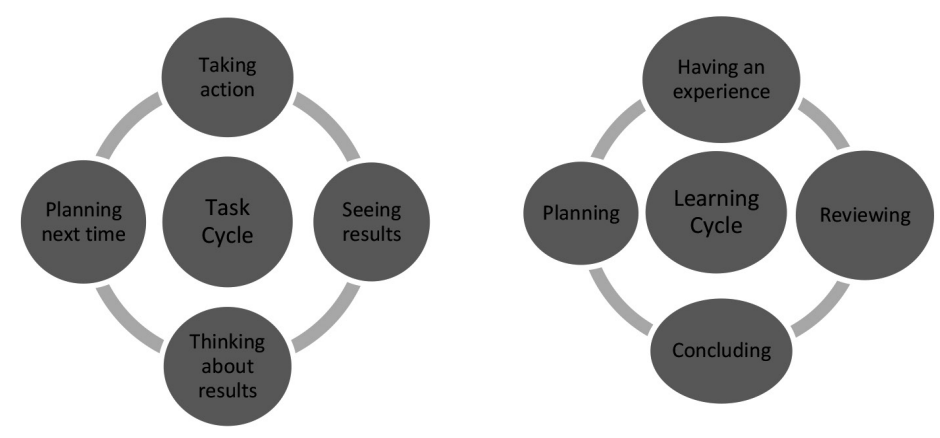

Figure 5.1. Task cycle and learning cycle (Mumford, 1993, p. 50) 
In summary, action learning is effective when working on real problems with a group of 'comrades in adversity' to find solutions using insightful questioning that utilises the shared knowledge of group members. Questioning is very important during action learning meetings, as yesterday's knowledge is often not useful to solve today's problems. Questioning should be supportive while also challenging the mental model of the person/s with the problem. Artefacts identified by practitioners that are common in an action learning program can be used to set up the action learning process. However, the group is likely to become self-sufficient once its members learn how to use the artefacts well. Members of our group also knew that within our organisation the 'action learning' meetings acted as a safety net where we could 'discuss the undiscussable' if everyone agreed to keep what happened at the meeting confidential. To be able to do this, an atmosphere of trust needs to be developed within the group.

\section{Action Research}

Kurt Lewin is generally credited with coining the term 'action research'. As he explained:

The research needed for social practice can best be characterized as research for social management or social engineering. It is a type of [action-research], a comparative research on the conditions and effects of various forms of social action, and research leading to social action. Research that produces nothing but books will not suffice. (Lewin, 1946 reproduced in Lewin, 1948, pp. 202-203)

His approach involves a spiral of steps, 'each of which is composed of a circle of planning, action and fact-finding about the result of the action' (Lewin, 1948, p. 206). http://infed.org/mobi/kurt-lewin-groups-experiential-learning-and-action-research/

Although Lewin is credited as the founder of action research, Argyris, Putnam and Smith $(1987$, p. 8) noted that Lewin 'never wrote a systematic statement of his views on action research'. This observation has a connotation similar to Pedler's statement about Revans not defining action learning. However, to be fair to Lewin, he died in 1947 soon after he first used the term 'action research'.

The SAGE Handbook of Action Research edited by Peter Reason and Hilary Bradbury is a valuable resource for action researchers across the world. Reason and Bradbury (2008, p. 4) define action research as:

a participatory process concerned with developing practical knowing in the pursuit of worthwhile human purposes. It seeks to bring together action and reflection, theory and practice, in participation with others, in the pursuit of practical solutions to issues of pressing concern to people, and more generally the flourishing of individual persons and their communities. 


\section{S. SANKARAN}

This definition reflects the development of action research from the initial thoughts of Lewin to its form that has emerged today through the contributions of prominent scholars in the field.

In my doctoral research (Sankaran, 1999) I adopted a simpler definition of action research, given by Bob Dick (2001, p. 21):

Action research 'pursues both action (change) and research (understanding) outcomes'. It achieves change through a participatory approach, often in conjunction with other change processes. The research is achieved by being responsive to the situation and by searching strenuously for disconfirming evidence. At the heart of AR is a cycle that alternates action and critical reflection.

This worked well for us in the context of the organisational change we were implementing in the company where I worked, which became my doctoral research project. Kemmis and McTaggart's (1988) concept of action research being a spiral of self-reflective cycles of Planning, Acting and Observing, Reflecting and Replanning also helped me to set up my action research process in stages.

Ortrun developed the CRASP (critical, reflective, accountable, self-evaluating and participative) model of action research for use in higher education, based on grounded theory developed from case studies (Zuber-Skerritt, 1991, p. 2). She often uses the working definition of action research developed with her colleagues during the First International Symposium on Action Research in Higher Education, Government and Industry held in Brisbane in 1989. During my doctoral research I found this working definition very useful.

If yours is a situation in which

- people reflect on and improve (or develop) their own work and their own situations

- by tightly inter-linking their reflection and action

- also making their experience public, not only to the participants but also to other persons interested in and concerned about the work and the situation, i.e., their (public) theories and practices of the work and the situation

and if yours is a situation in which there is increasingly

- data gathering by participants themselves (or with the help of others) in relation to their own questions

- participation (in problem posing and in answering questions) in decision making

- power sharing and the relative suspension of hierarchical ways of working towards industrial democracy

- collaboration among members of the group as a 'critical community'

- self-reflection, self-evaluation and self-management by autonomous and responsible persons and groups 
- learning progressively (and publicly) by doing and making mistakes in a 'self-reflective spiral' of planning, acting, observing, replanning etc.

- reflection that supports the idea of the '(self-)reflective practitioner'

then

- yours is situation in which ACTION RESEARCH is occurring (Altrichter et al., 1991, p. 8).

We found that our own action research intervention to change our work model to carry out projects reflected on many of the points included in this definition.

Two online courses offered from Australia to teach action research were also very useful in learning about how to set up an action research project. These were Action Research and Evaluation Online (AREOL) (http://www.aral.com.au/areol/ areolind.html) facilitated by Bob Dick, and Action Research on the Web (AROW) taught by Ian Hughes. The AROW program is now discontinued and the website is not available.

Similar to action learners, action researchers also adopt some key common values in their work. For Mary Brydon-Miller et al. (2003, p. 15), 'A respect for people and for the knowledge and experience they bring to the research process, a belief in the ability of democratic processes to achieve positive social change, and a commitment to action, these are the basic values which underlie our common practice as action researchers'. For Bob Dick (email 8 January 2015), the values of action research can be thought of as the 'governing variables' of Model II in action science, which is a variant of action research, founded by Chris Argyris. Argyris's (1982) Model I (theory-in-use) and Model II (espoused theory) contrast two sets of values - those we claim to hold (Model II) and those an uninvolved observer would deduce from our actual behaviour (Model I).

Dick (2015) suggests that from this point of view, action researchers would claim to hold such values as stated in Model II:

- valid information

- free and informed choice

- internal commitment to the choice, and

- constant monitoring of the implementation.

A book published recently by Rothwell (2015) states some principles of action research that can be considered to be its values:

Pragmatic: It addresses practical issues and links theory with practice.

Democratic: It involves people and also seeks to empower them to generate their own knowledge.

Extended epistemology: It accommodates many ways of knowing and valuing the experiential, narrative, aesthetic and conceptual. 
Value-oriented: It asks how we can contribute to the economic, political, psychological, and spiritual well-being of humans, communities, and the wider ecology.

Developmental: It evolves over time toward a more significant diagnostic model.

In summary, then, as Bob Dick and I explain:

Action research is not a single method or methodology, but refers to a variety of approaches that involves working collaboratively with people who are facing a concern that needs some deliberate action to be taken to address it. Such collaboration creates buy-in for implementing the change that accompanies the action. The group of people who are working together with the action researcher are treated as co-researchers rather than informants. Action research is a cyclic process alternating between action and reflection upon the action to initiate further action converging towards improving the situation of concern. (Sankaran \& Dick, 2015, pp. 211-212)

In addition, there are strong values that action researchers adhere to such as participation, equity, justice and the importance of democratic processes.

\section{Similarities and Differences between Action Learning and Action Research}

While action learning and action research have several similarities in their features, there are also some critical differences between them. Abraham asks us not to be confused with the two processes even though they both are 'problem-focussed, action oriented and utilise group dynamics' (Abraham, 2012, p. 6). Abraham explains that through Action Learning, Revans was:

more interested in 'questioning insight' than 'solving problems', whereas 'Action Research' was designed as a means by which change could be introduced in problematic situations to bring about a noticeable improvement. Revans places more emphasis on the development of managers, skills and abilities than Lewin, who was more concerned with making a contribution to science, and he accords outside experts a far lesser role.

While this is a useful differentiation, Revans did not support the use of outside experts in action learning because he felt that the knowledge required to solve problems rests within managers and insightful questioning helps to unearth this hidden knowledge.

Pedler and Burogyne (2008, p. 322) also note the many similarities between action learning and action research, particularly through 'a commitment to action and pragmatism and a reaction against detached research generating abstract knowledge, which is then disseminated through teaching from a position of assumed expertise'. They point out that the differences between the two can be seen in their starting points and development paths. While action learning seems to be dependent 
on the thought and practice of its founder Revans, action research has moved beyond Lewin's original conception of it. They also observe, 'Another apparently obvious difference is in the name action learning versus action research; action learning has become a radical alternative to teaching, while action research presents a striking juxtaposition to passive traditions of research, both positivist and interpretivist' (p. 322). Pedler and Burogyne (2008, p. 323) also contend that action research has become a more developed field 'both in practice and theory, and has been developed and taken forward by a wider community of scholars than action learning'.

Joe Raelin (1997, p. 21) pointed out the common basis of 'action technologies' (a term coined by Brooks and Watkins in 2002 to cover action learning, action research and action science). He sees it 'is that knowledge is to be produced in action. As opposed to "positivist" models that were designed to develop theories purposely separated from practice in order to predict truth, action research applied theory directly to the field with scholars and practitioners collaborating'. Raelin also claimed that action learning and action science evolved from action research (this may be contested by action learning scholars) and that action learning 'is based on the straightforward pedagogical notion that people learn most effectively when working on real-time problems occurring in their work setting'.

Ortrun also considers action learning and action research as 'linked-integrated' concepts located in the social sciences. In her view (Zuber-Skerritt, 2009, p. 6), "'Action Learning" means learning from and through action or concrete experience, as well as taking action as a result of this learning. Similarly "Action Research" is a cyclical iterative process of action and reflection on and in action'. Ortrun differentiates between action learning and action research by stating that while 'both include active learning, searching, problem solving and systematic inquiry ... Action Research is more systematic, rigorous, scrutinisable, verifiable, and always public (in verifiable or published written/electronic forms').

My own experience of using action learning and action research indicates that there are more similarities than differences between the two. This agrees with views published by the Action Learning and Action Research Association in Australia (http://www.alarassociation.org/pages/al-and-ar/action-learning):

I used to think that action research was the umbrella term, and action learning was an application of it. Some of my colleagues, I found, argue that action learning is the umbrella term. On reflection, I don't think it's worth debating.

As they were previously practised, I think a useful distinction could be made. In action learning, each participant drew different learning from different experience. In action research a team of people drew collective learning from a collective experience.

More recently, the advent of in-company action learning programs has begun to change this. The use of a team with a common project or problem leads to an action learning program which looks remarkably like action research. 


\section{S. SANKARAN}

There were also some differences, on average, in field of application. Action learning was more often used in organisational settings. Action research is more common in community and educational settings. This distinction, too, is beginning to blur.

I now wonder if the distinction is worth preserving.

I want to conclude this brief review with a question. If action learning and action research are similar in many respects, do people who practise these have common values? Apparently they do according to the Action Learning and Action Research Associations. See http://www.alarassociation.org/pages/al-and-ar/ alara-al_ar-principles

\section{COMBINING ACTION LEARNING AND ACTION RESEARCH}

Due to their similarities and common principles it is not difficult to combine action learning and action research to deliver management and research outcomes. As I noted above, my doctoral research used a combination of action research and action learning based on an elegant model proposed by Perry and Zuber-Skerritt (1992, p. 76) for doctoral programs. Although their model, shown in Figure 5.2, uses action research for the '(core) intervention projects' and 'thesis writing', we used 'action learning' for the 'intervention projects' as it suited our environment. In this workplace in Singapore, the Japanese corporation's policy was to encourage kaizen or continuous improvement in the organisation.

There are three cyclical processes used in this model.

The thesis action research represents the setting up of a (doctoral) research project where the perceived research problem leads to taking some action. This action could be a number of core projects that contribute to the observations required to collect data for the research. This data is analysed using critical reflection that could lead to further improvement to the research plan and how it is adjusted to be emergent and responsive.

The core projects follow a similar cycle but their main motivation is action with less emphasis on research, focussing on the task to be done. Refinements are made through a cyclical process using the steps shown in Figure 5.2.

New understandings developed through the reflections carried out in the thesis action research project help to set up the writing up of the project and its results for publication (usually a thesis, but also possibly journal articles or book). These steps may also be set up as a cyclical process within the project.

The combination of action research and action learning worked for us because there were two main aims for the project that we undertook.

1. Action research, naturally, suited my professional aims as project manager. There was a $\mathrm{PhD}$ thesis to be submitted. I aimed to write and submit a $\mathrm{PhD}$ thesis based on the intervention that was carried out to change the nature of project 


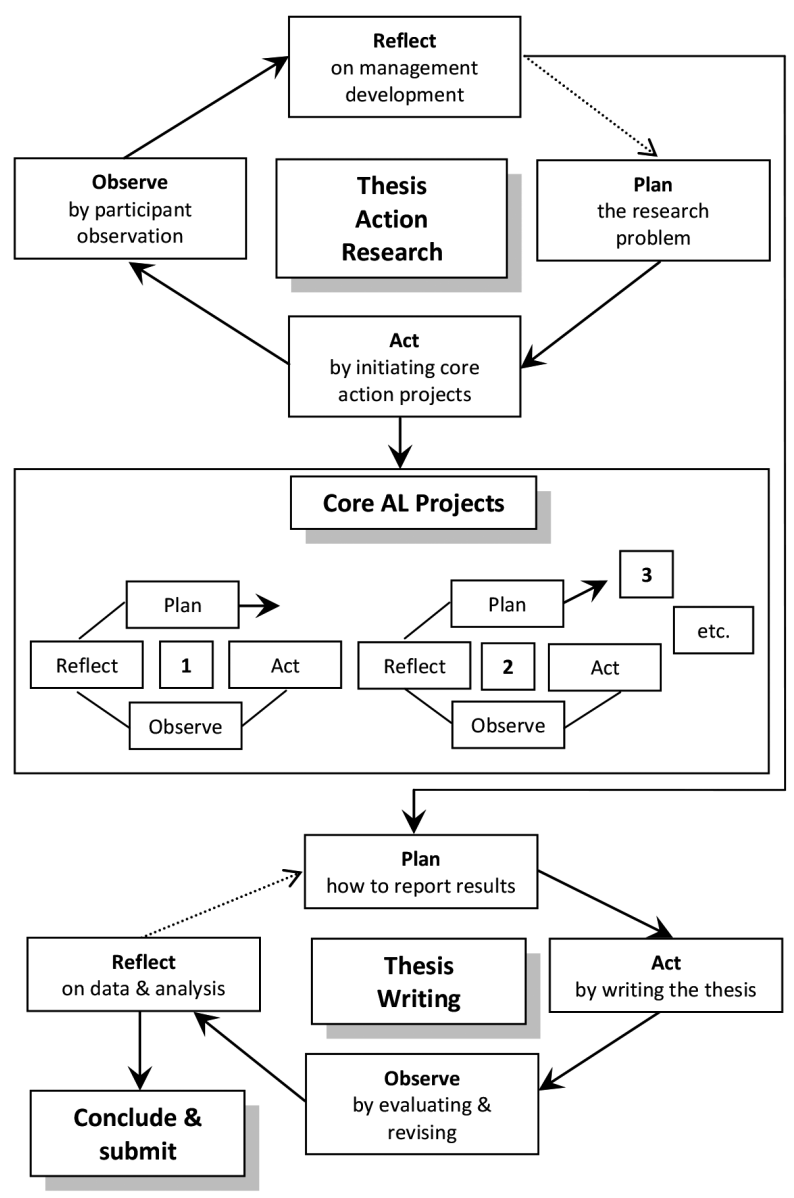

Figure 5.2. Combining action research and action learning in a doctoral thesis (Perry and Zuber-Skerritt, 1992, p. 76)

management in the organisation. The research had to be rigorously carried out, analysed and reported, and published making a contribution to knowledge.

2. Action learning best suited the purpose of the organisational change projects - developing in the organisation younger managers who would take on senior positions once the change project was completed. It also matched the political climate of the organisation, a Japanese company with kaizen or continuous improvement as its management philosophy.

As well as her scholarly contributions to and through ALAR, Ortrun has also developed the PALAR model as a structured action learning program that uses 
action research as a methodology to address a major organisational problem (ZuberSkerritt, 2002, p. 144). The PALAR model consists of eight phases:

1. Problem definition and needs analysis

2. Start-up workshop

3. Project work

4. Midway workshop with specialist input

5. Project work continued

6. Concluding workshop

7. Preparing for presentations and publications

8. Final presentation ad celebration

While this model was not adopted in our action research project, it was replicated in the group supervision process adopted by our two Australian supervisors. They used it to supervise as a group four doctoral students in Singapore - of whom I was one - in yearly face-to-face supervision sessions in Singapore. All four students were very effective in timely and successful completion of their doctoral studies (Sankaran et al., 2007).

Other scholars have also supported the use of action research in doctoral research. Dick (2002) states that action research is useful for doctoral research as both action and research can be important to the candidate. The action in action research often takes the form of a change or improvement one wants to implement at the workplace. The research helps learning and understanding, and publication of the study contributes to knowledge creation. These were the dual aims of the research that we undertook in our work organisation. Coghlan (2007) explores doing action research in your own organisation, showing how an executive action research doctorate can combine individual activity undertaken by the manager-researcher as first-person enquiry, the collaborative activities carried out by others as second-person enquiry, and the actionable knowledge contributed by the research to the academic and practitioner communities as the third-person contribution.

After I left industry and joined academia in 1999 I started supervising doctoral candidates who used action research as their methodology. One of these candidates, Simon Walker, adopted the Perry and Zuber-Skerritt model combining thesis and core action research projects to implement knowledge management in a large telecommunications company in Europe that had multiple branches across Europe and the United States (Walker \& Sankaran, 2014). I have also examined a doctoral thesis that used action research adopting this model.

\section{CONCLUSIONS}

Action learning and action research have many similarities despite the differences in their origins and purposes. Both rely on knowledge being produced in action, they are problem-focussed, used in groups, and rely on learning by doing. They can 
also be used effectively together for management development and postgraduate research. In this chapter I have focussed on the postgraduate research aspect where Ortrun has made a major contribution through her career as an academic worldwide. I have illustrated why using the model proposed by Ortrun and her colleagues was useful in my own research as well as in my supervision of doctoral students. I think combining action learning and action research is a very pragmatic way of carrying out a research project that has the dual aim of producing management outcomes while carrying out the rigorous research expected of a doctoral thesis or dissertation.

\section{Postscript}

As a novice action researcher I met Ortrun in the early 1990s in Brisbane, Australia, when I was beginning my doctoral research in Singapore as a manager. She encouraged me to take up action research with enthusiasm when I expressed some concerns about using it in my research due to my positivist background as a scientist and an engineer. After finishing my doctorate as a manager in industry, I joined Southern Cross University in New South Wales to teach in an MBA program. At that time Ortrun had been appointed to help the university become a centre for action research in Australia. After she left the university, I took up that role and established the Southern Cross Institute of Action Research. I have kept in touch with Ortrun through the activities of the Action Learning and Action Research Association (ALARA) of Australia (which she helped establish in 1991) and the Action Research World Congresses where she has taken major responsibilities. I feel privileged to be invited to contribute to a book to recognise the immense and valuable work carried out by Ortrun to promote both action learning and action research around the world.

\section{REFERENCES}

Abraham, S. (2012). Work-applied learning for change. Adelaide, South Australia: AIB Publications.

Altrichter, H., Kemmis, S., McTaggart, R., \& Zuber-Skerritt, O. (1991). Defining, confining or refining action research? In O. Zuber-Skerritt (Ed.), Action research for change and development (pp. 13-20). Aldershot, England: Gower.

Argyris, C. (1982). Reasoning, learning and action: Individual and organisational. San Francisco, CA: Jossey-Bass.

Argyris, C., Putnam, R., \& Smith, D. (1987). Action science: Concepts, methods, and skills for research and intervention. San Francisco, CA: Jossey-Bass.

Brydon-Miller, M., Greenwood, D., \& McGuire, P. (2003). What is action research? Action Research, 1(1), 9-28.

Coghlan, D. (2007). Insider action research doctorates: Generating actionable knowledge. Higher Education, 54, 293-306.

Dick, B. (2001), Action research: Action and research. In S. Sankaran, B. Dick, R. Passfield, \& P. Swepson (Eds.), Effective change management using action learning and action research: Concepts, frameworks, processes and applications (pp. 21-27). Lismore, New South Wales: Southern Cross University Press.

Dick, B. (2002). Postgraduate programs using action research. The Learning Organization, 9(4), 159-170.

Dick, B. (2015, January 8). Email communication with author. 


\section{S. SANKARAN}

Inglis, S. (1994). Making the most of action learning. Aldershot, England: Gower.

Kemmis, S., \& McTaggart, R. (1988). The action research planner (2nd ed.). Geelong, Victoria, Australia: Deakin University Press.

Lewin, K. (1946). Action research and minority problems, Journal of Social Issues, 2(4), 34-46.

Lewin, K. (1948). Action research and minority problems (Republished). In G. W. Lewin (Ed.), Resolving social conflicts: Selected papers on group dynamics (pp. 201-216). New York, NY: Harper \& Row.

McGill, I., \& Beatty, L. (2001). Action learning: A practitioner's guide (2nd ed.). London, UK: Kogan Page.

Mumford, A. (1993). How managers can develop managers. Aldershot, England: Gower.

Passfield, R. (1996). Action learning: A paradigm whose time has come. Action Learning and Action Research, 1(2), 14-29.

Pedler, M. (1997a). Introduction by Mike Pedler. In M. Pedler (Ed.), Action learning in practice (3rd ed.). Aldershot, England: Gower.

Pedler, M. (Ed.). (1997b). Action learning in practice (3rd ed.). Aldershot, England: Gower.

Pedler, M. (2008). Action learning for managers (2nd ed.). Aldershot, England: Gower.

Pedler, M., \& Burgoyne, J. (2008). Action learning. In P. Reason \& H. Bradbury (Eds.), The Sage handbook of action research (pp. 319-332). London, UK: Sage.

Pedler, M., Burgoyne, J., \& Brook, C. (2014). What has action learning learned to become? Action Learning: Research and Practice, 2(1), 49-68.

Perry, C., \& Zuber-Skerritt, O. (1992). Action research in graduate management research programs. Higher Education, 23, 195-208.

Raelin, J. A. (1997) Action learning and action science: Are they different? Organizational Dynamics, 26(1), 21-34.

Reason, P., \& Bradbury, H. (2008). Introduction. In P. Reason \& H. Bradbury (Eds.), The Sage handbook of action research (pp. 1-10). London, UK: Sage.

Revans, R. W. (1981). Management, productivity and risk: The way ahead. OMEGA International Review of Management Science, 9(2), 127-137.

Revans, R. (1983). Action learning: Its terms and character. Management Development, 21, 39-50.

Revans, R. (1998). ABC of action learning: Empowering managers to act and learn from action. The Mike Pedler Library, London, UK: Lemos and Crane.

Rothwell, W. J. (Ed.). (2015). Organization development fundamentals. Alexandria, VA: ATD Press.

Sankaran S. (1999). An action research study of management learning: Developing local engineering managers of a Japanese multinational company in Singapore ( $\mathrm{PhD}$ Thesis). Adelaide, South Australia: University of South Australia.

Sankaran, S., \& Dick, B. (2015). Linking theory and practice in using action-oriented methods. In B. Pasian (Ed.), Designs, methods and practices for research of project management (pp. 211-224). Aldershot, England: Gower.

Sankaran, S., \& Kumar, M. R., (2010). Implementing organizational change using action research, in two Asian cultures. Proceedings of Project Management Institute, PMI research and education conference 2010 (pp. 1-26). Project Management Institute, Washington, DC.

Sankaran, S., Hase, S., Dick, B., \& Davies, A. (2007). Singing different tunes from the same song sheet: Four perspectives of teaching the doing of action research. Action Research, Special Issue: The Praxis of Teaching Action Research, 5(3), 30-52.

Walker, S., \& Sankaran, S. (2014). A participatory action research study of knowledge management implementation in a large European telecommunication company in their UK office. Gibaran Journal of Applied Management, 6(2), 36-63.

Watkins, A., \& Brooks, K. E. (1994). A framework for using action technologies. New Directions for Adult and Continuing Education, 63, 99-111.

Zuber-Skerritt, O. (Ed.). (1991). Action research for change and development. Centre for the Advancement of Learning and Teaching, Brisbane: Griffith University. 
Zuber-Skerritt, O. (2002). A model for designing action learning and action research programs. The Learning Organization, 9(4), 143-149.

Zuber-Skerritt, O. (2009). Introduction. In O. Zuber-Skerritt \& Associates (Eds.), Action learning and action research: Songlines through interviews (pp. 1-21). Rotterdam, The Netherland: Sense Publishers.

\section{Shankar Sankaran}

Professor

Organisational Project Management

University of Technology Sydney

Australia 